\title{
Does SEC Rating Agency Certification Matter? The Case of A.M. Best
}

\author{
Lisa Fairchild ${ }^{1}$, Yoon $\operatorname{Shin}^{1} \&$ Yuxing Yan ${ }^{2}$ \\ ${ }^{1}$ Department of Finance, The Sellinger School of Business, Loyola University Maryland, 4501 N. Charles St., \\ Baltimore, MD 21210, USA \\ ${ }^{2}$ Department of Economics and Finance, Canisius College, 2001 Main Street, Buffalo, NY 14208, USA \\ Correspondence: Yoon Shin, Department of Finance, The Sellinger School of Business, Loyola University Maryland, \\ 4501 N. Charles St., Baltimore, MD 21210, USA. Tel: 410-617-2869
}

Received: July 17, 2015

doi:10.5430/ijfr.v6n4p10
Accepted: August 13, 2015

Online Published: August 19, 2015

URL: http://dx.doi.org/10.5430/ijfr.v6n4p10

\begin{abstract}
Some previous researchers such as Partnoy $(1999,2001)$ argue that the reputation of credit rating agencies such as Moody's and S\&P's may result from designation as a Nationally Recognized Statistical Rating Organization (NRSRO) by the SEC. By examining bond ratings for issues rated by A.M. Best and the yields of bonds rated by A.M. Best before and after the agency's receipt of the NRSRO designation, we examine the impact of NRSRO designation on the ratings of a credit rating agency and whether investor perception of the agency changed after receipt of the NRSRO designation. A.M. Best is an American credit rating agency that has specialized in the insurance industry for over 100 years. The agency was founded in 1899 and was given NRSRO designation on March 3, 2005. A.M. Best likely possessed a high level of expertise in assigning ratings in the insurance industry as well as an established reputation prior to being designated as an NRSRO. By examining the ratings assigned by A.M. Best and the yields of the bonds the agency rated, our empirical results indicate that neither the ratings assigned by A.M. Best or yields of the rated bonds changed after A.M. Best received NRSRO designation. Our findings suggest that the NRSRO designation does not affect the rating of A.M. Best or the perception of investors toward the credit risk of the bonds rated by the agency. Our findings are different from those of Shin and Moore (2008) and Kisgen and Strahan (2010), which examine the NRSRO designation of Dominion Bond Rating Service (DBRS) in Canada.
\end{abstract}

Keywords: reputation, rating agency, monopolistic power, government regulation, A.M. Best

\section{Introduction}

Before firms issue bonds, most of them pay a fee to credit rating agencies to obtain ratings. The Big Three rating agencies (S\&P, Moody's, and Fitch) control about 97\% of the global credit ratings markets. (Note 1) Previous studies (Hand, Holthausen, and Leftwich, 1992; Dichev and Piotroski, 2001; Behr and Güttler, 2008) show that the announcements of new ratings or rating changes convey new information to the markets because investors believe that rating agencies have specialized skills in assessing credit worthiness of issuers. In other words, because rating agencies disclose the important credit risk of debt issuers based on the private information provided by the issuers and reduce information asymmetry between the issuers and investors, rating announcements make a significant impact on the stock and bond returns of debt issuers. It is believed that S\&P's and Moody's, founded in 1916 and 1900 , respectively, have established a reliable relationship between ratings and default rates and earned a reputation as dependable credit risk assessors and monitors for about 100 years.

On the other hand, there is another argument that the certification of the Nationally Recognized Statistical Rating Organizations (NRSROs) by the U.S. Securities and Exchange Commission (SEC) is the most important factor of the power of rating agencies. Partnoy (1999 and 2001) argues that the designation of NRSRO provides rating agencies with monopolistic power. Thus, the reputation of raters originates from the designation, not from their specialized skills at evaluating credit risk. Partnoy (2001) claims that the profitability and size of Moody's and S\&P have increased significantly since their NRSRO designations in 1975. The NRSRO regulatory license entitles investors and issuers to use the ratings of NRSRO as reliable investment guidance and a vital financing protocol, respectively, because most institutional investors in the U.S. are not allowed to purchase bonds rated by non-NRSROs.

Recently several domestic and foreign rating agencies such as Egan-Jones Ratings Co. in the U.S. and Dominion Bond Rating Service (DBRS) in Canada obtained NRSRO status from the SEC. (Note 2) The SEC also approved the 
application of A.M. Best for the NRSRO designation on March 3, 2005. A.M. Best is a U.S. rating agency founded in 1899 with expertise in the insurance industry, while the Big Three have rated firms in all industries. Consequently, A.M. Best has enjoyed monopolistic power in the insurance industry over 100 years until the Big Three penetrated the market in the 1990s.

A.M. Best still assigns a greater number of ratings to insurance companies than the Big Three does. According to Bloomberg, while S\&P's has assigned long-term issuer credit ratings for 914 insurance companies in the U.S. from March 1, 2001 to February 28, 2009, A.M. Best has rated 1,145 insurance companies over the same period. More importantly, out of S\&P's 914 ratings, 354 ratings are "pi" ratings. S\&P's "pi" ratings are unsolicited ratings based on public information and unpaid by debt issuers. In other words, we conjecture that S\&P's has assigned "pi" ratings without the request of debt issuers to increase market share in insurance industry. On the other hand, A.M. Best has issued only solicited ratings, where the rating agency assigns ratings only if it receives rating fees from potential bond issuers. Additionally, even though A.M. Best has maintained a monopolistic position in the insurance industry, its NRSRO's approval came 30 years later than that of the Big Three.

The objective of this research is to study the impact of A. M. Best's NRSRO's approval. In particular, we compare the yields of new bonds and their ratings assigned by A.M. Best before and after the NRSRO designation and investigate whether there are any differences in ratings (supply side) and yield spreads (demand side) between the two periods. Because A.M. Best has maintained the NRSRO status since March 2005, the comparison periods are unique in analyzing the consequence of the designation. While we find that A.M. Best assigns lower mean rating after the certification in 2005 according to our univariate analysis, the rating difference disappears when we use multivariate analysis. Moreover, we also report that there is no yield difference between before and after the NRSRO certification after multivariate analyses. We conclude that A.M. Best did not change its ratings after its NRSRO designation in 2005, and bond investors are not influenced by the designation. Our results are different from those of Shin and Moore (2008) and Kisgen and Strahan (2010), which find that DBRS becomes more aggressive in credit market penetration in the U.S. by rating remarkably more issuers and assigning significantly lower ratings since receiving the NRSRO designation in 2003.

Our study makes important contributions to the existing literature. It is the first attempt to investigate regulation effects on an American rating agency, A. M. Best. A.M. Best has greater reputation and expertise in the insurance industry as well as a longer rating history than both Moody's and S\&P's, and our study is also the first research examining the rating agency with regard to the NRSRO certification. In particular, our research is extremely relevant to the argument of whether the ratings-based regulation associated with the NRSRO designation affects bond yields when a rating agency already has an established reputation or monopolistic power. Furthermore, the results of our study in the insurance industry could be helpful for determining the effectiveness of government regulation with respect to the certification of credit rating agencies. Therefore, our results are likely useful for SEC regulators when the promulgation of rules regarding credit rating agencies are under consideration.

The paper is structured as follows. The next section includes a short literature review and two hypotheses. Section III describes the data and research methodology, while section IV explains our empirical results, and section V concludes the paper.

\section{Literature Review and Hypothesis Development}

There are two types of existing research regarding the NRSROs. One type of study compares the influence of NRSROs with that of non-NRSROs in financial markets, while the other examines the regulatory effect of the NRSRO designation. Numerous previous studies provide evidence of the influence of NRSROs. For example, Hand, Holthausen, and Leftwich (1992), Dichev and Piotroski (2001), Behr and Güttler (2008), and Han, Shin, Moore, and Yi (2013) conclude that the announcements of new ratings or rating changes by the Big Three NRSROs result in a significant impact on the stock or bond prices in the U.S. or foreign financial markets. Additionally, Faulkender and Petersen (2006), Bosch and Steffen (2011) report that firms rated by Moody's or S\&P have better access to capital.

Moreover, Han, Pagano, and Shin (2012) and Li, Shin, and Moore (2006) find that Moody's and S\&P have a stronger reputation than non-NRSRO Japanese rating agencies (R\&I and JCR) in Japanese financial markets. (Note 3) $\mathrm{Li}$, Shin, and Moore (2006) report that the rating changes of Moody's and S\&P result in more significant stock market reactions than those of Japanese agencies, and Han, Pagano, and Shin (2012) claim that Japanese firms are able to sell bonds at lower yields, i.e., cheaper, if they obtain bond ratings from Moody's and S\&P rather than Japanese rating agencies. However, Beaver, Shakespeare, and Soliman (2006) report that investors respond more strongly to downgrades by Egan Jones, which obtained NRSRO status in 2008, than to those of Moody's in the U.S. market. (Note 4) 
On the other hand, Li, Shin, and Moore (2006) report that the ratings of NRSRO agencies (Moody's and S\&P) are significantly lower than those of non-NRSRO agencies (R\&I and JCR) in Japan, and Beaver, Shakespeare, and Soliman (2006) find that the ratings of a NRSRO agency (Moody's) are about one notch lower than a non-NRSRO agency (Egan Jones). These studies suggest that agencies with NRSRO status assign more conservative ratings than agencies without NRSRO status.

Moreover, there are only a couple of studies regarding the effects of NRSRO designations. According to Shin and Moore (2008) and Kisgen and Strahan (2010), the DBRS (Note 5) became more aggressive in credit market penetration and conservative in rating assignments after obtaining NRSRO certification. Shin and Moore (2008) find that DBRS assigned significantly lower ratings after receiving NRSRO designation in 2003. However, they do not find any differences in investor responses in terms of stock price changes before and after the designation. In addition, Kisgen and Strahan (2010) examine the yields to maturity of bonds rated by DBRS and find that the NRSRO certification alone does not affect bond yields after receiving the designation. Even though the results of these two studies imply that bond and stock investors are indifferent to the NRSRO designation of DBRS, there is no study regarding the receipt of NRSRO designation for an American rating agency, in particular, a rating agency with more than 100 years of experience and expertise in insurance industry.

The findings of Shin and Moore (2008) and Kisgen and Strahan (2010) lead us to the following two hypotheses.

Hypothesis 1: Investors pay the same yields on bonds rated by A.M. Best before and after the NRSRO designation.

Hypothesis 2: A.M. Best assigns same bond ratings before and after the NRSRO designation.

\section{Data and Research Methodology}

Unlike the methods used by Kisgen and Strahan (2010), which examine the yield to maturity of existing bonds, we investigate the offering yields of new bonds around the time of the NRSRO designation. In particular, we obtain the offering yields of 3,337 new corporate bonds and their ratings in insurance industry from S\&P's Capital IQ (henceforth denoted Capital IQ). (Note 6) Capital IQ also provides issue-specific information such as issue amount, maturity, S\&P's ratings, and coupon rates. We then merge these individual bonds into COMPUSTAT to collect issuer-specific financial information such as total long-term debt, total assets, and total revenue. In addition, we use Bloomberg to search for Moody's and Fitch ratings, and www.ambest.com to identify the ratings assigned by A.M. Best. The sample period begins in March 2001 and ends in February 2009. We also obtain the yield to maturity of Treasury securities from Bloomberg to calculate yield spreads between corporate bonds and risk-free Treasury securities for our sample period. We divide the total sample period into the following two sub-periods.

- Pre-Certification Period: March 1, 2001 - February 28, 2005;

- Post-Certification Period: March 3, 2005 - February 28, 2009.

We designate a pre- and post-certification period because A.M. Best obtained NRSRO certification on March 3, 2005. We compare the bond ratings and yields between the Pre-Certification Period and the Post-Certification Period.

We first calculate yield spreads between each corporate bond and a similar maturity Treasury security to incorporate the term structure of interest rates. Next, we compare differences in ratings and yield spreads between the pre- and post-certification period by testing mean differences and attempt to determine whether the NRSRO designation affected the ratings of A.M. Best, as well as the cost of bonds (i.e., offering yields) rated by A.M. Best. For instance, if there are no differences in ratings assigned during the pre- and post-periods, this may signal that A.M. Best did not change its rating practices after receiving the NRSRO designation. Additionally, we study the demand side of credit markets by examining yield differences between the two periods to gauge whether investors change their perception about the credit risk of the bonds rated by A.M. Best following the receipt of NRSRO status.

Because we conjecture that A.M. Best already has both a strong expertise and an established reputation in the insurance industry, the NRSRO certification may not affect investor perceptions. We hypothesize that the offering yields of newly issued bonds rated by A.M. Best between the pre and post periods are not different. We test yield differences with a differences-in-differences estimator approach. The differences-in-differences method is widely used to measure the effect of a policy change. (Note 7) Suppose we observe two groups of bonds before and after the NRSRO designation, with the treatment group being affected by the designation, and the control group unaffected by the designation. We examine any yield change that occurs to the control group and compare it to the change in the treatment group. The definition of each group is as follows:

- Treatment Group: Bonds rated by only A.M. Best 
- Control Group: Bonds rated by A.M. Best, Moody's, S\&P's or Fitch

The following differences-in-differences regression model (Equation 1) will be employed to test hypothesis 1:

$$
Y S=\alpha+\beta X+\gamma Y+\delta(X Y)+\Theta Z+\varepsilon
$$

The dependent variable $Y S$ represents yield spreads between new corporate bonds and comparable maturity Treasury securities. The definitions of the independent variables are given below:

$X(\mathrm{BEST})=$ the treatment variable equals 1 if a bond is rated by only A.M. Best and 0 otherwise;

$Y(\mathrm{POST})=$ the time variable equals 1 if a bond is issued after the NRSRO designation, and 0 otherwise;

$X Y($ INTER $)=$ interaction term between $\mathrm{X}$ and $\mathrm{Y}$;

Issue-specific variables (Z):

$\mathrm{MAT}=$ maturity of a bond;

$\mathrm{AMT}=$ natural $\log$ of issue amount;

$\mathrm{CALL}=$ a dummy variable equals 1 if a bond has a call option, and 0 otherwise;

RAT $=$ composite ratings, i.e. the average of the ratings by A.M. Best, Moody's, S\&P's or Fitch.

If $\delta=0$, we fail to reject the hypothesis that the offering yields of newly issued bonds rated by A.M. Best between the pre and post periods are not different. For Equation 1, we test three different models such as a fixed effects model with year dummies, a fixed effects model with year clustering, and a pooled linear regression model with cluster-robust standard errors. (Note 8)

Moreover, we employ the following ordered probit model, Equation 2, to examine Hypothesis 2.

$$
\mathrm{P}=\mu+\sigma \mathrm{Z}+\varphi \mathrm{W}+\lambda \mathrm{Y}+\nu
$$

where $\mathrm{P}$ is the observed bond ratings converted to numeric ratings. (Note 9) The definitions of explanatory variables are given below.

Issue-Specific variables (Z):

$\mathrm{YLD}=$ the offering yield of the bond on the issue date;

$\mathrm{AMT}=$ the $\log$ of issue amount of the bond.

Issuer-Specific variables $(W)$ :

LTD $=$ Total long-term debt ratio (total long-term debt / total assets);

$\mathrm{SOA}=$ Asset efficiency ratio (total sales / total assets);

MTB = market-to-book ratio (market value of equity / book value of equity);

Test variables $(Y)$ :

POST $=$ a dummy variable takes a value of 1 if a bond is issued after the NRSRO designation, and 0 otherwise;

If $\lambda=0$, we fail to reject the hypothesis that the bond ratings by A.M. Best between the pre and post periods are not different. We employ the AMT variable to control for size effect and YLD for market risk. We also use the issuer-specific variables associated with firm financial quality because A.M. Best (2013) employs such financial ratios as important determinants of bond ratings.

\section{Empirical Results}

Out of 1,145 insurance companies rated by A.M. Best from March 2001 to February 2009, we examine 3,337 bonds issued by 71 firms. We identify 1,100 newly issued bonds over the pre-certification period and 2,237 bonds during the post-certification period. Panel A of Table 1 shows the ratings distribution of new bonds rated in our sample while Panel B provides the annual distribution of yield spreads. In Panel A, we find that, out of 3,337 new bonds issued from 2001 to 2009 , only 11 bonds $(0.15 \%)$ have speculative grade ratings (bb+ and below) and 3,332 bonds (99.85\%) have investment grade ratings. Panel B describes the distributions of yield spreads by year. We report that the yield spreads increased during the global financial crisis in 2007-2009 and the majority of the newly issued bonds (59.98\%) were issued in 2004-2006 when the yield spreads were low. For example, the mean yield spread in 2008 is $1.97 \%$, which is more than two times of the annual mean yield spreads from 2002 to 2007 . We do not calculate the mean yield spread in 2009 because we have only one bond in that year. 
Table 1. Ratings distribution of A.M. Best

Panel A. Rating Distribution of New Bonds Rated by A.M. Best

\begin{tabular}{cccc}
\hline Letter Rating & Numeric Rating & $\mathrm{N}$ & Percent \\
\hline aaa & 1 & 11 & 0.33 \\
aa + & 2 & 12 & 0.36 \\
aa & 3 & 0 & 0 \\
aa- & 4 & 781 & 23.4 \\
$\mathrm{a}^{+}$ & 5 & 1144 & 34.28 \\
a & 6 & 71 & 2.13 \\
a- & 7 & 917 & 27.48 \\
bbb + & 8 & 307 & 9.2 \\
bbb & 9 & 80 & 2.4 \\
bbb- & 10 & 9 & 0.27 \\
bb+ \& below & 11 & 5 & 0.15 \\
\hline Total & & 3337 & 100 \\
\hline
\end{tabular}

Panel B. Annual new bond issues and mean yield spreads

\begin{tabular}{cccc}
\hline Year & N & Mean Yield Spread (bps) & Percent \\
\hline 2001 & 30 & 175 & 0.9 \\
2002 & 87 & 74 & 2.61 \\
2003 & 333 & 71 & 9.98 \\
2004 & 553 & 58 & 16.57 \\
2005 & 781 & 58 & 23.4 \\
2006 & 634 & 76 & 19 \\
2007 & 620 & 91 & 18.58 \\
2008 & 298 & 197 & 8.96 \\
2009 & 1 & n/a & 0 \\
\hline & 3337 & & 100
\end{tabular}

Bond ratings and yields are obtained from www.ambest.com, S\&P's Capital IQ, and Bloomberg. $\mathrm{N}$ is the number of new bonds rated by A.M. Best. Mean yield spreads are the differences between the yields of new corporate bonds and those of Treasury securities with comparable maturities. We convert the letter ratings to numeric ratings for empirical tests.

Table 2 presents the summary statistics for newly issued bonds rated by A.M. Best as well as for the bond issuers. While the mean offering yield is $5.02 \%$, the mean yield spread is 84 basis points. The mean issue amount is $\$ 41.84$ million, and mean maturity is 9.79 years. With respect to bond (numeric) ratings, A.M. Best assigns the highest mean rating (5.72), followed by S\&P's (5.89) and Moody's (6.82), respectively. The mean composite rating of 5.67 belongs to the investment-grade category (11 and below are speculative grades). (Note 10) Moreover, with regard to 71 bond issuers in our sample, we obtain 3,270 firm year observations. The mean total assets in our sample are $\$ 271,271.2$ million. The mean long-term debt ratio (long-term debt / total assets) is $2.14 \%$ and the mean asset efficiency ratio (total revenue / total assets) is $9.03 \%$. The market-to-book ratio (market value of equity / book value of equity) is 1.97 times. 
Table 2. Summary statistics

\begin{tabular}{cccc}
\hline & $\mathrm{N}$ & Mean & SD \\
\hline Best Rating & 3337 & 5.72 & 1.51 \\
Moody's Rating & 605 & 6.82 & 0.97 \\
S\&P's Rating & 351 & 5.89 & 1.98 \\
Composite Rating & 3337 & 5.67 & 1.49 \\
Issue Amount (\$m) & 3337 & 41.84 & 151.28 \\
Offering Yield (\%) & 3337 & 5.02 & 0.99 \\
Yield Spread (bps) & 3130 & 84 & 63 \\
Maturity (year) & 3337 & 9.79 & 7.55 \\
Total Assets (\$m) & 3270 & 271271.2 & 136754.7 \\
Long-Term Debt Ratio (\%) & 3270 & 2.14 & 0.02 \\
Asset Efficiency Ratio (\%) & 3270 & 9.03 & 0.04 \\
Market-to-Book Ratio (times) & 3269 & 1.97 & 6.72
\end{tabular}

Bond ratings, maturity, issue amount, and yields are obtained from www.ambest.com, S\&P's Capital IQ, and Bloomberg. Total assets, long-term debt ratio (long-term debt / total assets), assets efficiency ratio (total revenue / total assets), and market-to-book ratio (market value of equity / book value of equity) are collected from COMPUSTAT. $\mathrm{N}$ is the number of new bonds rated by A.M. Best. Mean yield spreads are the differences between the yields of new corporate bonds and those of Treasury securities with comparable maturities. Composite ratings are the mean ratings of bonds rated by A.M. Best and other rating agencies such as S\&P's, Moody's or Fitch. We convert the letter ratings to numeric ratings for empirical tests.

Table 3 presents t-test results of the yield spreads, maturity, and issue amounts between the pre-certification period and post-certification period of the NRSRO designation for each bond-specific or test variable. The difference in mean yield spreads between the pre- and post- periods is $-24.8 \mathrm{bps}(\mathrm{t}=-10.18)$, which is significant at the $1 \%$ level. Our interpretation of this result is that issuers pay a higher interest rate after receipt of the NRSRO designation by a rating agency. But, we do not know whether the higher spread over the post-period results from the global financial crisis or the NRSRO certification. We also find that there are significant mean yield spread differences between bonds rated by only A.M. Best and those rated by A.M. Best, Moody's, S\&P's, or Fitch. The former has a lower yield spread $($ mean $=76.2 \mathrm{bps})$ than the latter $($ mean $=105.45 \mathrm{bps})$ at the $1 \%$ significance level $(\mathrm{t}=11.69)$. In addition, callable bonds have higher mean spreads than non-callable bonds at the $1 \%$ level $(t=-13.36)$. Further, we find that there are significant mean differences in maturities and issue amounts between the pre- and post-NRSRO periods at the $1 \%$ level, respectively. The newly issued bonds in the post-period have a lower maturity and a smaller issue amount.

Table 3. T-test results of mean differences in yield spreads, maturity, and issue amounts

Yield Spread Difference (\%)

\begin{tabular}{ccccc}
\hline & $\mathrm{N}$ & Mean Yield Spread & Mean Difference & t-value \\
\hline Pre-NRSRO Period & 938 & 0.6672 & -0.248 & $(-10.18)^{* * *}$ \\
Post-NRSRO Period & 2192 & 0.9153 & & \\
\hline
\end{tabular}

Yield Spread Difference (\%)

\begin{tabular}{ccccc}
\hline & $\mathrm{N}$ & Mean Yield Spread & Mean Difference & t-value \\
\hline Non-Callable & 1038 & 0.6316 & -0.3132 & $(-13.36)^{* * *}$ \\
Callable & 2092 & 0.9449 & & \\
\hline
\end{tabular}


Yield Spread Difference (\%)

\begin{tabular}{ccccc}
\hline & $\mathrm{N}$ & Mean Yield Spread & Mean Difference & t-value \\
\hline Multiple Ratings & 845 & 1.0545 & 0.2925 & $(11.69)^{* * *}$ \\
A.M. Best only & 2285 & 0.762 & & \\
\hline
\end{tabular}

Maturity Difference (year)

\begin{tabular}{ccccc}
\hline & $\mathrm{N}$ & Mean Maturity & Mean Difference & t-value \\
\hline Pre-NRSRO Period & 1100 & 10.72 & 1.38 & $(4.99)^{* * *}$ \\
Post-NRSRO Period & 2237 & 9.34 & & \\
\hline
\end{tabular}

Issue Amount Difference (\$m)

\begin{tabular}{ccccc}
\hline & $\mathrm{N}$ & Mean Issue Amount & Mean Difference & t-value \\
\hline Pre-NRSRO Period & 1100 & 57.77 & 23.76 & $(4.28)^{* * *}$ \\
Post-NRSRO Period & 2237 & 34.01 & &
\end{tabular}

Bond ratings, maturity, issue amount, and yields are obtained from www.ambest.com, S\&P's Capital IQ, and Bloomberg. $\mathrm{N}$ is the number of new bonds rated by A.M. Best. Mean yield spreads are the differences between the yields of new corporate bonds and those of Treasury securities with comparable maturities. Multiple ratings are the ratings of the bonds rated by A.M. Best and other rating agencies such as S\&P's, Moody's or Fitch. The pre-certification period is from March 1, 2001 to February 28, 2005, and the post-certification period is from March 3, 2005 to February 28, 2009. The symbol ***,**, and * show significance at the $1 \%, 5 \%$, and $10 \%$ level, respectively.

In Table 4, we test mean differences for ratings and firm characteristics. We discover that the pre-period mean composite bond rating (5.27) is significantly higher than the post-period mean bond rating (5.87) at the $1 \%$ level $(t=$ -11.14). The pre-period mean A.M. Best rating is also higher than the post-period counterpart and significant at the $1 \%$ level $(\mathrm{t}=-9.73)$. Our results are consistent with the findings of Shin and Moore (2008) and Kisgen and Strahan (2010) that find that the post-period ratings of DBRS are lower than the pre-period ratings after receipt of the NRSRO designation. However, we do not know whether the NRSRO designation or the global financial crisis contributed the lower bond ratings. We compare firm characteristics between the two periods, and find that the post-period issuers have a significantly larger long-term debt ratio and a significantly lower asset efficiency ratio. For instance, the long-term debt ratio in the post-period is significantly higher than the pre-period $(t=-6.19)$, but asset efficiency ratio during the pre-period is significantly higher than the post-period $(t=14.79)$. Both of these ratios are significant at the $1 \%$ level. We do not find any significant difference for the market-to-book ratios between the two periods. Additionally, the mean total assets for issuers in the pre-period are significantly smaller than those in the post-period $(\mathrm{t}=-15.23)$. This suggests that the lower ratings assigned by A.M. Best after receipt of the NRSRO designation may be attributed to lower firm quality because many firms were adversely affected by the global financial crisis.

Table 4. T-test results for the differences of ratings and firm characteristics

Composite Rating Difference

\begin{tabular}{ccccc}
\hline & $\mathrm{N}$ & Mean Rating & Mean Difference & t-value \\
\hline Pre-NRSRO Period & 1100 & 5.27 & -0.6 & $(-11.14)^{* * *}$ \\
Post-NRSRO Period & 2237 & 5.87 & & \\
\hline
\end{tabular}

A.M. Best Rating Difference

\begin{tabular}{ccccc}
\hline & $\mathrm{N}$ & Mean Rating & Mean Difference & t-value \\
\hline Pre-NRSRO Period & 1100 & 5.36 & -0.53 & $(-9.73)^{* * *}$
\end{tabular}


$\begin{array}{lll}\text { Post-NRSRO Period } & 2237 & 5.89\end{array}$

Long-Term Debt Ratio Difference

\begin{tabular}{ccccc}
\hline & $\mathrm{N}$ & Mean Ratio & Mean Difference & t-value \\
\hline Pre-NRSRO Period & 1059 & 0.0185 & -0.0043 & $(-6.19)^{* * *}$ \\
Post-NRSRO Period & 2211 & 0.0228 & & \\
\hline
\end{tabular}

Asset Efficiency Ratio Difference

\begin{tabular}{ccccc}
\hline & N & Mean Ratio & Mean Difference & t-value \\
\hline Pre-NRSRO Period & 1059 & 0.1059 & 0.0231 & $(14.79)^{* * *}$ \\
Post-NRSRO Period & 2211 & 0.0829 & & \\
\hline
\end{tabular}

Market-to-Book Ratio Difference

\begin{tabular}{ccccc}
\hline & $\mathrm{N}$ & Mean Ratio & Mean Difference & t-value \\
\hline Pre-NRSRO Period & 1058 & 1.88 & -0.121 & $(-0.48)$ \\
Post-NRSRO Period & 2211 & 2.01 & & \\
\hline
\end{tabular}

Total Assets Difference (\$m)

\begin{tabular}{ccccc}
\hline & N & Mean Assets & Mean Difference & t-value \\
\hline Pre-NRSRO Period & 1059 & 220415 & -75214 & $(-15.23)^{* * *}$ \\
Post-NRSRO Period & 2211 & 295630 & & \\
\hline
\end{tabular}

Bond ratings, maturity, issue amount, and yields are obtained from www.ambest.com, S\&P's Capital IQ, and Bloomberg. Total assets, long-term debt ratio (long-term debt / total assets), assets efficiency ratio (total revenue / total assets), and market-to-book ratio (market value of equity / book value of equity) are collected from COMPUSTAT. $\mathrm{N}$ is the number of new bonds rated by A.M. Best. The pre-certification period is from March 1, 2001 to February 28, 2005, and the post-certification period is from March 3, 2005 to February 28, 2009. The symbol $* * *, * *$, and $*$ show significance at the $1 \%, 5 \%$, and $10 \%$ level, respectively. Composite ratings are the mean ratings of bonds rated by A.M. Best and other raters such as S\&P's, Moody's or Fitch. The letter ratings of rating agencies are converted into numeric ratings. For example, S\&P's ratings are converted as follows: AAA=1, AA+=2, $\mathrm{AA}=3, \mathrm{AA}-=4, \mathrm{~A}+=5, \mathrm{~A}=6, \mathrm{~A}-=7$, and etc.

Table 5 contains the results of regression analysis (Equation 1) related to Hypothesis 1 with three different models. Model 1 displays a fixed effects model with year dummies, Model 2 employs a fixed effects model controlling for year clustering, and Model 3 conducts a pooled linear regression model with cluster-robust standard errors. In all three models, the coefficient of the INTER variable is not significant $(\mathrm{t}=-0.64$ in Model $1, \mathrm{t}=-0.55$ in Model 2, and $t=-1.13$ in Model 3) at any level. This result suggests that the NRSRO designation does not affect the yields of newly issued bonds rated by A.M. Best. On the other hand, we find that the coefficient of the POST variable is positive and significant $(t=3.02$ in Model $1, t=5.27$ in Model 2, and $t=9.31$ in Model 3$)$ at the $1 \%$ significance level for every model, suggesting that the yields of the post-period are higher than those of the pre-period. We also document that the global financial crisis increase the yield spread significantly because the coefficients of the 2007 and 2008 year dummy variables in Model 1 are significant at the $5 \%$ and $1 \%$ levels $(t=2.36$ and $t=17.20)$, respectively.

As expected, we confirm that a longer maturity (MAT), a larger issue amount (AMT), and the existence of call option (CALL) increases yield spreads significantly. For instance, the coefficient of the AMT variable is positive and significant at the $1 \%$ level for each model $(t=27.99$ in Model 1, 10.31 in Model 3, and $t=20.23$ in Model 3, respectively). In addition, the coefficient of the RAT variable is positive and significant in all models, implying that lower composite ratings by A.M. Best, Moody's, S\&P's or Fitch increase interest rates. On the other hand, the ratings of A.M. Best alone do not affect the cost of debt because the coefficient of the BEST variable is not 
significant at any level. We conclude that there are no significant yield differences for the bonds rated by A.M. Best before and after receipt of NRSRO designation, and the findings suggest that the NRSRO designation does not affect the yields of the bonds rated by A.M. Best.

Table 5. Empirical results of linear regression models

\begin{tabular}{|c|c|c|c|}
\hline & Model 1 & Model 2 & Model 3 \\
\hline \multirow[t]{2}{*}{ BEST } & -0.0425 & -0.0425 & -0.0472 \\
\hline & $(-1.42)$ & $(-1.18)$ & $(-1.25)$ \\
\hline \multirow[t]{2}{*}{ POST } & 0.1625 & 0.1624 & 0.3469 \\
\hline & $(3.02)^{* * *}$ & $(5.27)^{* * *}$ & $(9.31)^{* * *}$ \\
\hline \multirow[t]{2}{*}{ INTER } & -0.0228 & -0.0228 & -0.0489 \\
\hline & $(-0.64)$ & $(-0.55)$ & $(-1.13)$ \\
\hline \multirow[t]{2}{*}{ AMT } & 0.1131 & 0.1131 & 0.1575 \\
\hline & $(27.99)^{* * *}$ & $(10.31)^{* * *}$ & $(20.23)^{* * *}$ \\
\hline \multirow[t]{2}{*}{ RAT } & 0.0442 & 0.0442 & 0.0344 \\
\hline & $(8.38)^{* * *}$ & $(2.11)^{*}$ & $(3.50)^{* * *}$ \\
\hline \multirow[t]{2}{*}{ MAT } & 0.0083 & 0.0082 & 0.0064 \\
\hline & $(7.01)^{* * *}$ & $(1.89)^{*}$ & $(4.01)^{* * *}$ \\
\hline \multirow[t]{2}{*}{ CALL } & 0.1798 & 0.1798 & 0.1492 \\
\hline & $(9.61)^{* * *}$ & $(4.93)^{* * *}$ & $(5.58)^{* * *}$ \\
\hline \multirow[t]{2}{*}{2001} & 0.7145 & & \\
\hline & $(8.25)^{* * *}$ & & \\
\hline \multirow[t]{2}{*}{2002} & 0.0783 & & \\
\hline & $(1.28)$ & & \\
\hline \multirow[t]{2}{*}{2003} & 0.1092 & & \\
\hline & $(2.33)^{* *}$ & & \\
\hline \multirow[t]{2}{*}{2004} & 0.0384 & & \\
\hline & $(0.88)$ & & \\
\hline \multirow[t]{2}{*}{2005} & -0.0037 & & \\
\hline & $(-0.06)$ & & \\
\hline \multirow[t]{2}{*}{2006} & 0.0551 & & \\
\hline & $(0.83)$ & & \\
\hline \multirow[t]{2}{*}{2007} & 0.1588 & & \\
\hline & $(2.36)^{* *}$ & & \\
\hline \multirow[t]{2}{*}{2008} & 1.1652 & & \\
\hline & $(17.20)^{* * *}$ & & \\
\hline $\bar{N}$ & 3130 & 3130 & 3130 \\
\hline R-SQ & 0.8574 & 0.3446 & 0.362 \\
\hline
\end{tabular}

Model 1 is a fixed effects model with year dummies, Model 2 a fixed effects model controlling for year clustering, and Model 3 a pooled linear regression model with cluster-robust standard errors. The dependent variable is yield spreads, which are the differences between the yields of new corporate bonds and those of Treasury securities with comparable maturities, and the definition of independent variables is listed below.

MAT: maturity (year) of new bonds;

AMT: natural log of issue amount (\$m); 
CALL: a dummy $=1$ if a bond has a call option and 0 otherwise;

POST: a dummy $=1$ if a bond is issued after the NRSRO designation and 0 otherwise;

BEST: a dummy $=1$ if a bond is rated by A.M. Best only and 0 if a bond has multiple ratings;

INTER: an interaction term between BEST and POST;

RAT: composite ratings (the mean ratings of bonds rated by A.M. Best and other rating agencies such as S\&P's, Moody's or Fitch).

$\mathrm{N}$ is the number of bonds. The symbol ***,**, and * show significance at the $1 \%, 5 \%$, and $10 \%$ level, respectively.

Table 6 describes the test results of the ordered probit model (Equation 2) with year dummy variables. (Note 11) We find that the coefficient of the POST variable is not significant at any level $(z=-0.06)$. In contrast to our findings in Table 4 (univariate analysis), there is no rating difference for ratings assigned before and after the receipt of NRSRO certification after we control for important rating determinants such as offering yields, the long-term debt ratio, the asset efficiency ratio, the market-to-book ratio, and the issue amount. (Note 12) We employ LTD, SOA, and MTB variables to control for issuer-specific financial quality, AMT for the size effect, and YLD for market risk. (Note 13) We report that a greater issue size (AMT) results in higher ratings $(\mathrm{z}=3.84)$ and the coefficient is significant at the $1 \%$ level. Consistent with A.M. Best (2013), we also find that, while a larger market-to-book ratio (MTB) and a larger asset efficiency ratio (SOA) results in significantly higher ratings $(z=-6.67$ and -3.88 , respectively) at the $1 \%$ level, a larger long-term debt ratio (LTD) results in lower bond ratings $(\mathrm{z}=16.11)$.

Table 6. Empirical results of the Ordered Probit Model

\begin{tabular}{ccccc}
\hline Variable & Coefficient & SD & Z-stat & P-value \\
\hline YLD & 0.026 & 0.0256 & 1.01 & 0.311 \\
AMT & 0.0474 & 0.0123 & $(3.84)^{* * *}$ & 0.000 \\
LTD & 26.9244 & 1.6717 & $(16.11)^{* * *}$ & 0.000 \\
SOA & -2.2409 & 0.5769 & $(-3.88)^{* * *}$ & 0.000 \\
MTB & -0.0233 & 0.0035 & $(-6.67)^{* * *}$ & 0.000 \\
POST & -0.0067 & 0.1168 & -0.06 & 0.954 \\
& & & & \\
\hline N & 3269 & & & \\
LR Chi-SQ (13) & 549.06 & & & \\
Prob. $>$ Chi-SQ & 0.0000 & & & \\
Pseudo R-SQ & 0.0573 & & & \\
\hline
\end{tabular}

The dependent variable is A.M. Best ratings converted to numeric ratings. The definition of explanatory variables is as follows.

AMT: natural log of issue amount (\$m);

YLD: offering yields (\%) of new bonds;

LTD: total long-term debt ratio (total long-term debt / total assets);

SOA: asset efficiency ratio (total revenue / total assets);

MTB: market-to-book ratio (market value of equity / book value of equity); 
POST: a dummy $=1$ if a bond is issued after the NRSRO designation and 0 otherwise);

$\mathrm{N}$ is the number of bonds rated by A.M. Best. The symbol ***, **, and * show significance at the $1 \%, 5 \%$, and $10 \%$ level, respectively.

\section{Conclusion}

Some previous researchers conclude that the reputation of rating agencies is attributable to being designated as a Nationally Recognized Statistical Rating Organization (NRSRO). In contrast, we believe that NRSRO designation may have no effect on the ratings or investors' perception of a rating agency if the agency has long-standing expertise and an established reputation. Because A.M. Best has assigned ratings in the insurance industry for over 100 years, we use A. M. Best to examine the effect of the receipt of the NRSRO designation on a rating agency with a long-standing record of expertise and an established reputation. Our empirical results indeed confirm our conjecture because there are no significant differences in A.M. Best ratings and the yield spreads of the bonds rated by the agency when the pre- and post- NRSRO designation periods are compared. These findings suggest that the NRSRO designation does not affect the ratings of A.M. Best or the perception of investors toward bonds rated by the agency. Our findings are different from those of Shin and Moore (2008) and Kisgen and Strahan (2010), that show that the DBRS significantly changed its rating policy after the receipt of the NRSRO designation.

\section{References}

A.M. Best. (2013). Best's Credit Rating Methodology. Retrieved from http://www3.ambest.com/ambv/ratingmethodology/default.aspx

Beaver, W., Shakespeare, C., \& Soliman, M. (2006). Differential properties in the ratings of certified vs. non-certified bond rating agencies. Journal of Accounting and Economics, 42, 303-334. http://dx.doi.org/10.1016/j.jacceco.2006.06.002

Behr, P., \& Güttler, A. (2008). The informational content of unsolicited ratings. Journal of Banking and Finance, 32, 587-599. http://dx.doi.org/10.1016/j.jbankfin.2007.04.021

Bosch, O., \& Steffen, S. (2011). On syndicate composition, corporate structure, and the certification effect of credit ratings. Journal of Banking and Finance, 35, 290-299. http://dx.doi.org/10.1016/j.jbankfin.2010.08.002

Card, D., \& Krueger, A. (1994). Minimum Wages and Employment: A Case Study of the Fast Food Industry in New Jersey and Pennsylvania. The American Economic Review, 84, 316-361.

Dichev, I., \& Piotroski, J. (2001). The long-run stock returns following bond ratings changes. Journal of Finance, 56, 173-203. http://dx.doi.org/10.1111/0022-1082.00322

Faulkender, M., \& Petersen, M. (2006). Does the source of capital affect capital structure?. The Review of Financial Studies, 19, 45-79. http://dx.doi.org/10.1093/rfs/hhj003

Han, S., Moore, W., Shin, Y., \& Yi, S. (2013). Unsolicited Versus Solicited: Credit Ratings and Bond Yields. Journal of Financial Services Research, 43, 293-319. http://dx.doi.org/10.1007/s10693-012-0137-z

Han, S., Pagano, M., \& Shin, Y. (2012). Rating Agency Reputation, the Global Financial Crisis, and the Cost of Debt. Financial Management, 41, 849-884. http://dx.doi.org/10.1111/j.1755-053X.2012.01204.x

Hand, J., Holthausen, R., \& Leftwich, R. (1992). The effect of bond rating changes on bond and stock prices. Journal of Finance, 47, 733-752. http://dx.doi.org/10.1111/j.1540-6261.1992.tb04407.x

Kiel, K., \& McClain, K. (1995). Housing Prices during Siting Decision Stages: The Case of an Incinerator from Rumor through Operation. Journal of Environmental Economics and Management, 28, 241-255. http://dx.doi.org/10.1006/jeem.1995.1016

Kisgen, D., \& Strahan, P. (2010). Do Regulation Based on Credit Ratings Affect a Firm's Cost of Capital? The Review of Financial Studies, 23, 4324-4347. http://dx.doi.org/10.1093/rfs/hhq077

Li, J., Shin, Y., \& Moore, W. (2006). Reactions of Japanese Markets to Changes in Credit Ratings by Global and Local Agencies. Journal of Banking and Finance, 30, 1007-1021. http://dx.doi.org/10.1016/j.jbankfin.2005.05.026

Partnoy, F. (1999). The Siskel and Ebert of Financial Markets: Two Thumbs Down for the Credit Rating Agencies. Washington University Law Quarterly, 77(3). http://dx.doi.org/10.2139/ssrn.167412 
Partnoy, F. (2001). The Paradox of Credit Ratings. University of San Diego School of Law, Law and Economics Research Paper No.20.

Shin, Y., \& Moore, W. T. (2008). Effects of National Recognition on the Influence of Credit Rating Agencies: The Case of Dominion Bond Rating Service. Financial Decisions, 1-28.

\section{Notes}

Note 1. S\&P assigned 1,190,500 ratings (42\%), Moody's 1,039,187 (37\%), and Fitch 505,024 (18\%) out of 2,816,599 ratings registered with the U.S. Securities and Exchange Commission in 2011 (The Wall Street Journal, "Challengers Take Aim at Credit-Rating Titans," October 17, 2011, p. C8).

Note 2. Egan-Jones obtained the NRSRO recognition in 2008, and DBRS had it in 2003.

Note 3. The SEC awarded NRSRO status to R\&I (Rating \& Investment Information) and Japan Credit Rating Agency (JCR), in 2007. R\&I and JCR are the first Asian rating agencies to have acquired the certification. But, R\&I withdrew its designation in 2011.

Note 4. While bond issuers pay for the ratings of the Big Three or A.M. Best, investors pay for those of Egan Jones.

Note 5. DBRS (Dominion Bond Rating Service) is a privately owned Canadian credit rating agency founded in 1976.

Note 6 . We collect only fixed rate coupon bonds with greater than one-year maturity and exclude any floating rate or zero-coupon bonds.

Note 7. I will follow the differences-in-differences methods employed by Card and Krueger (1994) and Kiel and McClain (1995).

Note 8 . We do not test a random effects model due to an endogeneity concern.

Note 9. The letter ratings of A.M. Best are converted into numeric ratings as follows: aaa $=1, a^{+}=2$, aa $=3$, aa $=4$, $\mathrm{a}^{+}=5, \mathrm{a}=6, \mathrm{a}-=7$, and etc.

Note 10. The mean composite rating is the average rating of A.M. Best, S\&P's, Moody's, and Fitch. We do not report Fitch rating in Table 2 because it has less than 100 ratings.

Note 11. We do not report the coefficients of the year dummy variables in Table 6. But, they are available upon request.

Note 12. We also test an ordered probit model controlling for year clustering, and the results are similar.

Note 13. We find that the issue amount of each bond is a better control variable for size effect than the total assets of each issuer, and the offering yield of each bond provides also a better control for market risk than Treasury yield of a comparable maturity bond on the issue date. 